\title{
PENGARUH RASIO KESEHATAN BANK TERHADAP VOLUME PEMBIAYAAN BANK UMUM SYARIAH DI INDONESIA
}

\author{
Irsad Andriyanto ${ }^{1}$, Aprilia Inge Prastika² \\ 1,2Institut Agama Islam Negeri Kudus, Kudus \\ $\square$ irsad.smg@gmail.com
}

\begin{abstract}
: This research aims to analyze the effect of financial ratios on financing successfully channeled by Sharia Commercial Banks in Indonesia in 20152018. The bank's ratio is measured through CAMELS ratios (Capital, Asset Quality, Management, Earning, Liquidity, Sensitivity to Market Risk) for each aspect. Capital aspects are measured using the Capital Adequacy Ratio (CAR), asset quality (Asset Quality) is measured using Non Performing Financing (NPF), profitability (Earning) is measured using Return on Assets (ROA) and Operational Expenses to Operating Revenues (BOPO), and liquidity (Liquidity) is measured using Financing to Deposit Ratio (FDR). The samples are 13 Sharia Commercial Banks with the observation period from January 2015 till May 2018. The data obtained through Sharia Banking Statistics (SPS) are then processed by multiple linear regression analysis. The results showed that the $N P F$ and BOPO had a negative effect on the financing volume of sharia commercial banks, while ROA had a positive effect. In other way, the CAR and FDR have no significant effect on the financing volume of sharia commercial bank. This is because the capital is used to cover troubled financing and to maintain public trust.
\end{abstract}

Keywords : finance; investment; financial ratio; CAMELS.

\section{LATAR BELAKANG}

Sebagai salah satu bentuk dari perbankan nasional, bank syariah mendasarkan kegiatan operasionalnya pada syariat (hukum) Islam. Dalam Undang-Undang No. 21 tahun 2008 tentang perbankan syariah pasal 1 disebutkan bahwa perbankan syariah adalah segala sesuatu yang menyangkut tentang bank syariah dan unit usaha syariah, mencakup kelembagaan, kegiatan usaha, serta cara dan proses dalam melaksanakan kegiatan usahanya. Bank syariah dikembangkan sebagai lembaga bisnis keuangan yang melaksanakan kegiatan usahanya sejalan dengan prinsip-prinsip dasar dalam ekonomi Islam yang tidak hanya berfokus pada tujuan komersial tetapi juga mempertimbangkan perannya dalam memberikan kesejahteraan secara luas bagi masyarakat (Indonesia, 2008).

Bank syariah pertama yang berdiri di Indonesia yaitu Bank Muamalat Indonesia (BMI) pada tanggal 1 November 1991 yang diprakarsai oleh MUI, ICMI dan beberapa pengusaha muslim. Bank Muamalat Indonesia dapat dikategorikan kepada Islamic Commercial Banking (ICB) karena BMI didirikan secara khusus menggunakan prinsip syariah. Jenis ICB ini kemudian diikuti oleh Bank Syariah Mandiri (BSM) pada tahun 
1999 dan Bank Syariah Mega Indonesia (BSMI) pada tahun 2004. Belakangan pendirian bank umum ini diikuti pula oleh beberapa bank konvensional seperti BNI, BRI dan BPD. Bank konvensional ini menjadikan bank umum syariah sebagai salah satu unit usahanya. Oleh sebab itu bank umum ini diistilahkan dengan Islamic Banking Unit (IBU), yakni bank umum konvensional yang membuka unit usaha syariah .

Penyaluran dana yang disalurkan kepada masyarakat dalam bentuk pembiayaan digunakan sebagai modal kerja yang dapat menggerakkan roda perekonomian masyarakat. Namun pada kenyataannya keputusan bank di dalam menyalurkan kredit memiliki banyak risiko. Berdasarkan Laporan Perkembangan Keuangan Syariah Indonesia tahun 2017 yang terpublikasi dalam situs resmi Otoritas Jasa Keuangan, hasil penilaian profil risiko terhadap BUS (Bank Umum Syariah) selama tahun 2017, menunjukkan bahwa persentase jumlah BUS yang memiliki profil risiko Moderate to High mencapai 23\%, Moderate 54\% dan Low to Moderate mencapai 39\%. Jumlah tersebut meningkat dibandingkan profil risiko BUS selama 2016 (Otoritas Jasa Keuangan, 2017).

Pembiayaan yang dilaksanakan oleh bank syariah tentunya dalam rangka membuat bank syariah menjadi bank yang sehat dan memiliki keberlanjutan dalam melangsungkan fungsi intermediasi. Oleh sebab itu ketika bank menyalurkan pembiayaan harus memperhatikan ketentuan-ketentuan yang berkaitan dengan tingkat kesehatan bank. Penilaian terhadap kesehatan bank dilakukan secara kuantitatif terhadap berbagai aspek melalui rasio keuangan yang dapat dihitung melalui laporan keuangan bank. Diantara rambu-rambu kesehatan bank yang harus dimiliki oleh bank syariah dapat dilihat dari kondisi dan perkembangan perbankan syariah dari sisi permodalan dinilai dengan rasio CAR (Capital Adequacy Ratio), kualitas asset dinilai dengan rasio NPF (Non Performing Financing), rentabilitas dinilai dengan rasio ROA (Return on Total Asset) dan BOPO (Biaya Operasional terhadap Pendapatan Operasional), serta likuiditas dinilai dengan rasio FDR (Financing to Deposit Ratio). Aspek manajemen dan sensitivitas terhadap risiko pasar tidak dilakukan penilaian karena penilaian kedua aspek merupakan faktor kualitatif dan dalam pengukurannya tidak menggunakan rasio keuangan.

Tabel 1 Pergerakan CAR, NPF, ROA, BOPO , FDR dan Volume Pembiayaan (pihak ketiga bukan bank) Bank Umum Syariah periode 2015-2018

\begin{tabular}{ccccccc}
\hline Tahun & $\begin{array}{c}\text { Volume } \\
\text { Pembiayaan }\end{array}$ & CAR & NPF & ROA & BOPO & FDR \\
\hline 2015 & Rp 149.287 M & $15,05 \%$ & $5,30 \%$ & $0,46 \%$ & $97,30 \%$ & $90,72 \%$ \\
2016 & Rp 156.623 M & $14,87 \%$ & $5,55 \%$ & $0,48 \%$ & $96,96 \%$ & $87,53 \%$ \\
2017 & Rp 184.354 M & $16,42 \%$ & $4,49 \%$ & $0,98 \%$ & $92,03 \%$ & $81,78 \%$ \\
2018 & Rp 192.292 M & $20,46 \%$ & $3,95 \%$ & $1,35 \%$ & $88,64 \%$ & $80,45 \%$ \\
\hline
\end{tabular}

Sumber : Statistik Perbankan Syariah, 2018

Dapat disimpulkan bahwa rasio CAR selama 4 tahun terakhir mengalami pertumbuhan yang baik di atas $12 \%$ meskipun pada tahun 2016 rasio CAR mengalami penurunan dari $15,05 \%$ menjadi $14,87 \%$, namun demikian penyaluran pembiayaan pada 2017 tetap mengalami kenaikan dari Rp 156.623 M menjadi Rp 184.354 M. Sedangkan pergerakan rasio NPF juga sangat fluktuatif, di mana nilai NPF tertinggi tercatat pada tahun 2016 yang menembus batas maksimal NPF 5\% yaitu sebesar 5,55\%. Pada 2017 rasio NPF mengalami penurunan menjadi 4,49\% dari 5,55\% pada 2016, dan pada tahun 2018 rasio NPF mengalami penurunan kembali menjadi 3,95\%. Meskipun pada saat nilai NPF tinggi dan sudah menembus angka 5\%, bank syariah tetap meningkatkan pembiayaan pada tahun berikutnya. Rasio NPF menggambarkan 
kualitas pembiayaan yang buruk dan bermasalah. Kedua fenomena ini menunjukkan adanya gap yang menunjukkan penyimpangan dari teori yang ada.

\section{TEORI DAN METODE}

\subsection{Penilaian Kesehatan Bank}

Penilaian kesehatan Bank Syariah dilakukan berdasarkan Peraturan Bank Indonesia (PBI) No. 9/1/PBI/2007 tentang Sistem Penilaian Tingkat Kesehatan Bank Umum Berdasarkan Prinsip Syariah yang berlaku mulai 24 Januari 2007. Dari hasil penjelasan Deputi Gubernur, Bank Indonesia Siti Chalimah Fadjrijah menjelaskan bahwa penerapan ini dilakukan dengan memperkirakan produk dan jasa perbankan syariah ke depan kian beragam dan kompleks sehingga eksposur risiko yang dihadapi juga meningkat. Meningkatnya eksposur risiko tersebut akan megubah profil risiko Bank Syariah, yang pada gilirannya akan mempengaruhi tingkat kesehatan bank tersebut. Dalam penilaian tingkat kesehatan, Bank Syariah telah memasukkan risiko yang melekat pada aktivitas bank (inherent risk), yang merupakan bagian dari proses penilaian manajemen risiko (Bank Indonesia, 2007).

Bank Umum Syariah wajib melakukan penilaian tingkat kesehatan bank secara triwulanan, yang meliputi faktor-faktor: Permodalan (Capital), Kualitas aset (Asset Quality), Rentabilitas (Earning), Likuiditas (Liquidity), Sensitivitas terhadap risiko pasar (Sensitivity to market risk), dan Manajemen (Management). Sesuai Surat Edaran Bank Indonesia Nomor 15/15/DPNP tertanggal 29 April 2013, cakupan tingkat kesehatan Bank Umum Syariah meliputi faktor-faktor sebagai berikut (BI, 2013) :

a) Permodalan (Capital)

Penilaian permodalan dimaksudkan untuk menilai kecukupan modal bank dalam mengamankan eksposur risiko posisi dan mengantisipasi eksposur risiko yang akan muncul. Komponen penilaiannya mencakup :

1) Kecukupan pemenuhan KPMM, merupakan rasio utama

2) Kemampuan modal inti dan PPAP dalam mengamankan risiko hapus buku (write-off), merupakan rasio penunjang

3) Kemampuan modal inti untuk menutup kerugian pada saat likuidasi

4) Trend/pertumbuhan KPMM

5) Kemampuan internal bank untuk menambah modal

6) Intensitas fungsi keagenan bank syariah, merupakan rasio pengamatan (observed)

7) Modal inti dibandingkan dengan dana mudharabah

8) Deviden payout ratio

9) Akses kepada sumber permodalan (external support)

10)Kinerja keuangan pemegang saham untuk meningkatkan permodalan bank.

b) Kualitas Aset (Asset Quality)

Penilaian kualitas aset dimaksudkan untuk menilai kondisi asset bank, termasuk antisipasi atas risiko gagal bayar dari pembiayaan (credit risk) yang akan muncul. Komponen penilaiannya mencakup:

1) Kualitas aktiva produktif bank, merupakan rasio utama

2) Risiko konsentrasi penyaluran dana kepada debitur inti, merupakan rasio penunjang

3) Kualitas penyaluran dana kepada debitur inti 
4) Kemampuan bank dalam menangani/mengembalikan aset yang telah dihapus buku

5) Besarnya pembiayaan nonperforming,

6) Tingkat kecukupan agunan, merupakan rasio pengamatan

7) Proyeksi/perkembangan kualitas aset produktif

8) Perkembangan/trend aktiva produktif bermasalah yang direstrukturisasi.

c) Rentabilitas (Earning)

Penilaian rentabilitas dimaksudkan untuk menilai kemampuan bank dalam menghasilkan laba. Komponen penilaiannya mencakup:

1) Net operating margin (NOM), merupakan rasio utama

2) Return on assets (ROA), merupakan rasio penunjang

3) Rasio efisiensi kegiatan operasional (REO)

4) Rasio aktiva yang dapat menghasilkan pendapatan

5) Diversifikasi pendapatan

6) Proyeksi pendapatan bersih, operasional utama (PPBO)

7) Net structural operating margin, merupakan rasio pengamatan

8) Return on equity (ROE)

9) Komposisi penempatan dana pada surat berharga atau pasar keuangan

10)Disparitas, imbal jasa tertinggi dengan terendah

11)Pelaksanaan fungsi edukasi

12)Pelaksanaan fungsi sosial

13)Korelasi antara tingkat bunga di pasar dengan return atau bagi hasil yang diberikan oleh bank syariah

14)Rasio bagi hasil dana investasi

15)Penyaluran dana yang diwrite-off dibandingkan dengan biaya operasional.

d) Likuiditas (Liquidity)

Penilaian likuiditas dimaksudkan untuk menilai kemampuan bank dalam memelihara tingkat likuiditas yang memadai termasuk antisipasi atas risiko likuiditas yang muncul. Komponen penilaiannya mencakup:

1) Besarnya aset jangka pendek dibandingkan dengan kewajiban jangka pendek, merupakan rasio utama

2) Kemampuan aset jangka pendek, kas dan secondary reserve dalam memenuhi kewajiban jangka pendek, merupakan rasio penunjang

3) Ketergantungan kepada dana deposan inti

4) Pertumbuhan dana deposan inti terhadap total dana pihak ketiga

5) Kemampuan bank dalam memperoleh dana dari pihak lain apabila terjadi mistmach, merupakan rasio pengamatan

6) Ketergantungan pada dana antarbank.

e) Sensitivitas atas Risiko Pasar (Sensitivity to Market Risk)

Penilaian sensitivitas atas risiko pasar dimaksudkan untuk menilai kemampuan keuangan bank dalam mengantisipasi perubahan risiko pasar yang disebabkan oleh pergerakan nilai tukar. Penilaian sensitivitas atas risiko pasar dilakukan dengan menilai besarnya kelebihan modal yang digunakan untuk menutup risiko bank dibandingkan dengan besarnya risiko kerugian yang timbul dari pengaruh perubahan risiko pasar. 
f) Manajemen (Management)

Penilaian manajemen dimaksudkan untuk menilai kemampuan manajerial pengurus bank dalam menjalankan usaha sesuai prinsip manajemen umum, kecukupan manajemen risiko dan kepatuhan bank terhadap ketentuan bank yang terkait dengan prinsip kehati-hatian maupun kepatuhan terhadap prinsip syariah dan komitmen bank kepada Bank Indonesia. Komponen penilaiannya mencakup:

1) Kualitas manajemen umum terkait dengan penerapan good corporate governance

2) Kualitas penerapan manajemen risiko

3) Kepatuhan terhadap ketentuan baik yang terkait dengan prinsip kehatihatian maupun kepatuhan terhadap prinsip syariah serta komitmen kepada Bank Indonesia.

Penilaian faktor finansial dilakukan secara kuantitatif dengan melakukan pembobotan terhadap peringkat faktor, untuk saat ini dilakukan pembobotan faktor permodalan, kualitas aset, rentabilitas, likuiditas dan sensitivitas atas risiko pasar. Faktor-faktor ini dinilai secara kuantitatif melalui rasio-rasio keuangan dan kualitatif dengan mempertimbangkan unsur judgement. Rasio-rasio keuangan dimaksudkan dibedakan menjadi (Arifin Zainul, 2012):

a) Rasio utama, merupakan rasio yang memiliki pengaruh kuat (high impact) terhadap tingkat kesehatan bank.

b) Rasio penunjang, adalah rasio yang berpengaruh secara langsung terhadap rasio utama.

c) Rasio pengamatan adalah rasio tambahan yang digunakan dalam analisis dan pertimbangan.

Dalam penelitian ini, ada 5 (lima) rasio indikator yang dipilih dari aspek kesehatan bank yang digunakan untuk mengukur pengaruhnya terhadap volume pembiayaan yang disalurkan oleh bank umum syariah yaitu (Bank Indonesia, 2004):

a) Aspek permodalan menggunakan Capital Adequacy ratio (CAR)

Kecukupan modal merupakan faktor yang penting bagi bank dalam rangka pengembangan usaha dan menampung risiko kerugian. CAR adalah rasio kecukupan modal bank untuk menutup kemungkinan kerugian di dalam perkreditan atau dalam perdagangan surat-surat berharga. Bank Indonesia menetapkan modal (Capital Adequacy Ratio/CAR) sebagai kewajiban penyediaan modal minimum yang harus selalu dipertahankan oleh setiap bank sebagai suatu proporsi tertentu dari total Aktiva Tertimbang Menurut Risiko (ATMR) atau secara matematis :

$$
\mathrm{CAR}=\frac{\text { Modal }}{\text { Aktiva Tertimbang Menurut Risiko (ATMR) }} \times 100 \%
$$

Aktiva tertimbang menurut risiko adalah nilai total masing-masing aktiva bank setelah dikalikan dengan masing-masing bobot risiko aktiva tersebut. Aktiva yang paling tidak berisiko diberi bobot $0 \%$ dan aktiva yang paling berisiko diberi bobot $100 \%$. Dengan demikian, ATMR menunjukkan nilai aktiva berisiko yang memerlukan antisipasi modal dalam jumlah yang cukup. Pengertian modal bagi bank yang didirikan dan berkantor pusat di Indonesia menurut Paket Kebijakan 29 Mei 1993 terdiri atas modal inti dan modal pelengkap dengan penjelasan sebagai berikut: 
1) Modal inti berupa: Modal disetor, agio saham, modal sumbangan, cadangan umum, cadangan tujuan, laba yang ditahan, laba tahun lalu, laba tahun berjalan lalu dikurangi dengan goodwill yang ada dalam pembukuan bank dan kekurangan jumlah penyisihan penghapusan aktiva produktif dan jumlah yang seharusnya dibentuk sesuai dengan ketentuan Bank Indonesia.

2) Modal pelengkap berupa: Cadangan revaluasi aktiva tetap, penyisihan penghapusan aktiva produktif, modal pinjaman dan pinjaman subordinasi.

Ketentuan CAR pada prinsipnya disesuaikan dengan ketentuan yang berlaku Standar CAR secara internasional, yaitu sesuai standar Bank for International Sattlement (BIS) Internasional dan sejak September 1995, otoritas moneter Indonesia menetapkan ketentuan Indonesia CAR sebagai berikut :

Tabel 2 Ketentuan CAR dan Bank Indonesia per Septeber 1995

\begin{tabular}{cccc}
\hline Jenis Bank & Setelah 2 th & Setelah 4 th & Setelah 6 th \\
\hline Bank Devisa Baru & $10 \%$ & $12 \%$ & $12 \%$ \\
\hline Bank Devisa Lama & $9 \%$ & $10 \%$ & $12 \%$ \\
\hline
\end{tabular}

Penerapan aturan tersebut merupakan kelanjutan aturan sebelumnya yang hanya mewajibkan CAR minimal 8\%. Untuk meningkatkan kinerja dan memperhatikan prinsip kehati-hatian, otoritas moneter berusaha meningkatkan kewajiban CAR (Nasih, Laila, \& Dewikarina, 2013). Faktor utama yang mendorong pengembangan metode kecukupan modal tersebut adalah kenyataan bahwa modal merupakan sumber daya yang sangat mahal sehingga bank harus mengelolanya seefisiensi dan seefektif mungking. Sementara itu, tujuan dari pengawasan bank adalah untuk memastikan bahwa bank beroperasi dengan aman dan sehat. Untuk itu, bank harus menjaga modal dan cadangan yang cukup untuk mendukung risiko yang timbul dari bisnisnya (Ibrahim \& Rahmati, 2017).

b) Aspek kualitas aset menggunakan Non Performing Financing (NPF)

Dalam berbagai peraturan yang diterbitkan Bank Indonesia tidak dijumpai pengertian dari "pembiayaan bermasalah". Begitu juga istilah Non Performing Financings (NPFs) untuk fasilitas pembiayaan maupun istilah Non Performing Loan (NPL) untuk fasilitas kredit tidak dijumpai dalam peraturan-peraturan yang diterbitkan Bank Indonesia. Namun dalam setiap Statistik Perbankan Syariah yang diterbitkan oleh Direktorat Perbankan Syariah Bank Indonesia dapat dijumpai istilah Non Performing Financings (NPFs) yang diartikan sebagai "Pembiayaan Non-Lancar mulai dari kurang lancar sampai dengan macet".

Pembiayaan bermasalah tersebut, dari segi produktivitasnya (performancenya) yaitu dalam kaitannya dengan kemampuannya dalam menghasilkan pendapatan bagi bank, sudah berkurang/menurun bahkan mungkin tidak ada lagi. Bahkan dari segi bank sudah tentu mengurangi pendapatan, memperbesar biaya pencadangan, yaitu PPAP (Penyisihan Penghapusan Aktiva Produktif), sedangkan dari segi nasional mengurangi kontribusinya terhadap pembangunan dan pertumbuhan ekonomi. Dengan demikian dapat disimpulkan bahwa pembiayaan bermasalah adalah pembiayaan yang kualitasnya berada dalam golongan kurang lancar, diragukan dan macet (Ikatan Bankir Indonesia, 2016).

Sedangkan menurut Mudrajat Kuncoro dan Suharjono yang dikutip oleh Ismail menjelaskan bahwa kredit bermasalah adalah suatu keadaan dimana nasabah sudah tidak sanggup membayar sebagian atau seluruh kewajibannya kepada bank seperti yang telah diperjanjikan. Kedit bermasalah (Non performing loan) 
merupakan kredit yang menunggak melebihi 90 hari. Non Performing loan dibagi menjadi tiga, yaitu :

1) Kredit kurang lancar

Kredit kurang lancar terjadi bila debitur tidak dapat membayar angsuran pinjaman pokok dan/atau bunga antara 91 hari sampai dengan 180 hari.

2) Kredit diragukan

Kredit diragukan terjadi dalam hal debitur tidak dapat membayar angsuran pinjaman pokok dan/atau pembayaran bunga antara 181 hari sampai dengan 270 hari.

3) Kredit macet

Kredit macet terjadi bila debitur tidak mampu membayar berturut-turut lebih dari 270 hari.

Besarnya nilai Non Performing Financing dapat dihitung menggunakan rumus:

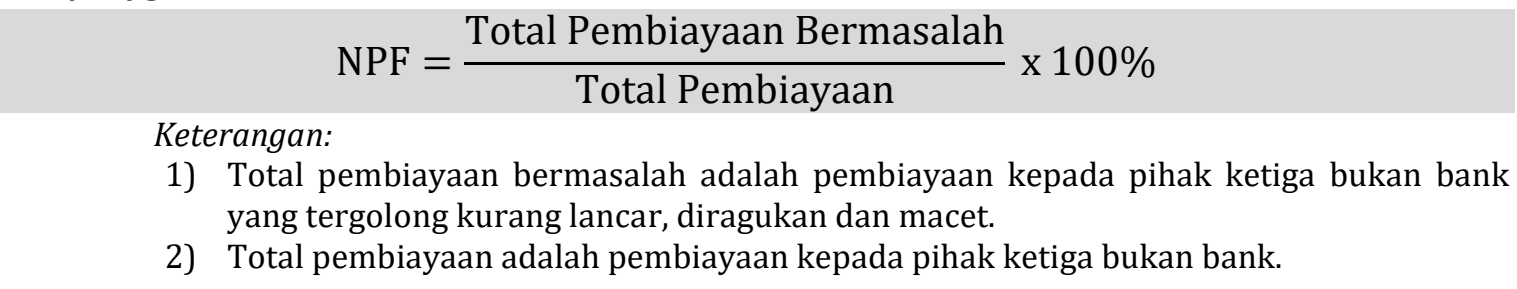

Rasio Non Performing Financing dibagi menjadi dua yakni Gross dan Net. Semakin tinggi rasio NPF Gross, semakin tinggi pembiayaan bermasalah dengan kolektabilitas kurang lancar, diragukan dan macet. Namun harus juga dilihat rasio NPF Net-nya yaitu rasio setelah pembiayaan bermasalah tersebut dikurangi cadangan kerugian penurunan nilai (CKPN) atau penyisihan penghapusan aktiva produktif (PPAP). Rasio NPF yang menjadi acuan Bank Indonesia maksimal 5\%. Jika tinggi rasio NPF Net sebuah bank di atas $5 \%$, bank tersebut dianggap mempunyai risiko pembiayaan yang tinggi.

c) Aspek Rentabilitas, diukur dengan menggunakan Return On Total Assets (ROA) dan Biaya Operasional terhadap Pendapatan Operasional (BOPO)

1) Return on Total Assets (ROA)

Rasio yang mengukur keberhasilan manajemen dalam menghasilkan laba secara keseluruhan dengan cara membandingkan antara laba sebelum pajak dengan total aset. Rasio ini juga menggambarkan perputaran aktiva yang diukur dari volume penjualan. Semakin besar rasio Return on Total Assets suatu bank, maka semakin besar pula tingkat keuntungan yang dicapai bank tersebut dan semakin baik pula posisi bank tersebut dari penggunaan aset. Semakin kecil rasio ini mengindikasikan kurangnya kemampuan manajemen bank dalam mengelola aktiva untuk meningkatkan pendapatan dan atau menekan biaya. Berdasarkan Surat Edaran Bank Indonesia No. 6/23/DPNP Tahun 2004, perolehan laba cukup tinggi, atau rasio ROA berkisar antara 0,5\% sampai dengan 1,25\% yang menempatkan bank dalam peringkat 3. Semakin kecil peringkat bank, maka semakin bagus karena bank memiliki laba yang semakin besar.

Return on Total Assets dapat dihitung menggunakan rumus sebagai berikut:

$$
\text { ROA }=\frac{\text { Laba Sebelum Pajak }}{\text { Total aktiva }} \times 100 \%
$$


Rasio ROA sangat penting bagi perbankan, mengingat keuntungan yang memadai diperlukan untuk mempertahankan sumber-sumber modal bank. Perubahan rasio ROA dapat disebabkan antara lain :

a. Lebih banyak asset yang digunakan sehingga menambah operating income dalam skala yang lebih besar.

b. Adanya kemampuan manajemen untuk mengalihkan portofolio/surat berharga ke jenis yang menghasilkan income lebih tinggi.

c. Adanya kenaikan tingkat bunga secara umum

d. Adanya pemanfaaatan aset-aset yang semula tidak produktif menjadi lebih produktif.

2) Biaya Operasional terhadap Pendapatan Operasional (BOPO)

Biaya operasional terhadap pendapatan operasional (BOPO) adalah rasio rentabilitas yang menunjukkan perbandingan antara total beban operasional dengan total pendapatan operasional yang dimiliki bank. Rasio yang sering disebut rasio efesiensi ini sering digunakan untuk mengukur kemampuan manajemen bank dalam mengendalikan biaya operasional terhadap pendapatan operasional. Semakin kecil rasio ini berarti semakin efisien biaya operasional yang dikeluarkan bank yang bersangkutan sehingga kemungkinan suatu bank dalam kondisi bermasalah semakin kecil. Beban operasional adalah beban operasional termasuk beban bagi hasil dan bonus (disetahunkan) sedangkan pendapatan operasional adalah pendapatan penyaluran dana. Berdasarkan Surat Edaran Bank Indonesia No. 6/23/DPNP Tahun 2004, tingkat efisiensi cukup baik atau rasio BOPO berkisar antara $94 \%$ sampai $96 \%$.

Biaya Operasional terhadap Pendapatan Operasional dapat dihitung menggunakan rumus sebagai berikut:

$$
\text { BOPO }=\frac{\text { Biaya Operasional }}{\text { Pendapatan Operasional }} \times 100 \%
$$

d) Aspek likuiditas menggunakan Financing to Deposit Ratio (FDR)

Financing to Deposit Ratio (FDR) adalah perbandingan antara pembiayaan yang diberikan oleh bank dengan dana pihak ketiga yang berhasil dihimpun oleh bank. Rasio ini dipergunakan untuk mengukur sampai sejauh mana dana pinjaman yang bersumber dari dana pihak ketiga digunakan oleh bank. Tinggi rendahnya rasio ini menunjukkan tingkat likiditas bank. Semakin tinggi angka FDR suatu bank, dapat digambarkan sebagai bank yang kurang likuid dibandingkan dengan bank yang mempunyai angka risiko lebih kecil. Termin FDR digunakan untuk bank syariah sedangkan LDR untuk bank konvensional (Dendawijaya, 2009).

Berdasarkan Surat Edaran Bank Indonesia No 26/5/BPPP tanggal 29 Mei 1993, besarnya Financing to Deposit Ratio ditetapkan oleh Bank Indonesia tidak melebihi $110 \%$. Yang berarti bank boleh memberikan kredit atau pembiayaan yang melebihi jumlah dana pihak ketiga yang berhasil dihimpun asalkan tidak melebihi $110 \%$.

Finacing to Deposit Ratio dapat dihitung menggunakan rumus sebagai berikut:

$$
\text { FDR } / \text { LDR }=\frac{\text { Pembiayaan } / \text { Pinjaman yang diberikan }}{\text { Dana Pihak Ketiga }} \times 100 \%
$$

Semakin besar penyaluran dana dalam bentuk kredit dibandingkan dengan deposit atau simpanan masyarakat pada suatu bank, membawa konsekuensi 
semakin besarnya risiko yang harus ditangggung oleh bank yang bersangkutan. Oleh sebab itu, tujuan penting dari perhitungan FDR atau LDR ini adalah untuk mengetahui serta menilai sampai seberapa jauh bank memiliki kondisi sehat dalam menjalankan operasi atau kegiatan usahanya. Dengan kata lain, rasio ini digunakan sebagai suatu indikator untuk mengetahui tingkat kerawanan suatu bank.

\subsection{Pembiayaan}

Pembiayaan dalam bank Islam adalah penyediaan dana atau tagihan yang dipersamakan dengan itu berupa (Alamsyah, 2012):

a) Transaksi bagi hasil dalam bentuk Mudharabah dan Musyarakah

b) Transaksi sewa dalam bentuk Ijarah atau sewa dengan opsi perpindahan hak milik dalam bentuk Ijarah Muntahiyah bit Tamlik

c) Transaksi jual beli dalam bentuk piutang Murabahah, Salam dan Istishna'

d) Transaksi pinjam meminjam dalam bentuk piutang Qardh, dan

e) Transaksi multijasa dengan menggunakan akad Ijarah dan Kafalah.

Berdasarkan persetujuan atau kesepakatan antara lembaga keuangan dengan pihak lain yang mewajibkan pihak yang dibiayai dan/atau diberi fasilitas dana untuk mengembalikan dana tersebut setelah jangka waktu tertentu dengan imbalan, tanpa imbalan atau bagi hasil. Dengan demikian dalam praktiknya pembiayaan adalah:

a) Penyerahan nilai ekonomis sekarang atas kepercayaan dengan harapan mendapatkan kembali suatu nilai ekonomi yang sama dikemudian hari.

b) Suatu tindakan atas dasar perjanjian yang dalam perjanjian tersebut terdapat jasa dan balas jasa (prestasi dan kontra prestasi) yang keduanya dipisahkan oleh unsur waktu.

c) Pembiayaan adalah suatu hak, dengan hak mana seorang dapat mempergunakannya untuk tujuan tertentu, dalam batas waktu tertentu dan atas pertimbangan tertentu pula.

\subsection{Kerangka Pikir dan Pengembangan Hipotesis}

Berdasarkan tinjauan pustaka dan kerangka pemikiran diatas, maka dapat diajukan hipotesis penelitian sebagai berikut :

a) Pengaruh Capital Adequacy Ratio (CAR) terhadap Volume Pembiayaan.

Permodalan yang cukup atau banyak sangat penting karena modal bank dimaksudkan untuk memperlancar operasional sebuah bank termasuk penyaluran pembiayaan. Adapun hipotesis yang diajukan dalam penelitian ini adalah:

H1: Capital Adequacy Ratio (CAR) berpengaruh positif terhadap Volume Pembiayaan pada Bank Umum Syariah di Indonesia.

b) Pengaruh Non Performing Financing (NPF) terhadap Volume Pembiayaan.

Semakin tinggi NPF maka semakin ketat kebijakan kredit atau analisis pembiayaan yang dilakukan oleh manajemen bank, sedangkan semakin rendah NPF mengindikasikan bahwa bank telah mampu mengelola risiko kredit dari aktivitas penyaluran dana, sehingga bank mampu menyalurkan pembiayaan jauh lebih besar. Adapun hipotesis yang diajukan dalam penelitian ini adalah :

H2 : Non Performing Financing (NPF) berpengaruh negatif terhadap Volume Pembiayaan pada Bank Umum Syariah di Indonesia. 
c) Pengaruh Return on Total Aset (ROA) terhadap Volume Pembiayaan.

Semakin besar ROA suatu bank, maka semakin besar pula tingkat keuntungan yang dicapai bank tersebut dan semakin baik pula posisi bank tersebut dari penggunaan aset. Semakin kecil rasio ini mengindikasikan kurangnya kemampuan manjemen bank dalam mengeola aktivitas untuk meningkatkan pendapatan dan atau menekan biaya. Aktivitas yang dilakukan bank untuk memperoleh pendapatan yang paling dominan adalah melalui penyaluran pembiayaan. Sehingga ketika ROA yang dihasilkan tinggi maka pembiayaan yang disalurkan bank mengalami peningkatan. Adapun hipotesis yang diajukan dalam penelitian ini adalah :

H3 : Return on Total Aset (ROA) berpengaruh positif terhadap Volume Pembiayaan pada Bank Umum Syariah di Indonesia.

d) Pengaruh Biaya Operasional terhadap Pendapatan Operasional (BOPO) terhadap Volume Pembiayaan.

BOPO adalah rasio rentabilitas yang juga sering disebut sebagai rasio efisiensi, digunakan untuk mengukur kemampuan manajemen bank dalam mengendalikan biaya opersional. Semakin kecil rasio ini berarti semakin efisien biaya operasional yang dikeluarkan bank yang bersangkutan sehingga kemungkinan suatu bank dalam kondisi bermasalah semakin kecil. Dengan demikian, semakin banyak penyaluran dana yang akan dilakukan oleh bank karena kondisi bank yang baik dan sehat. Adapun hipotesis yang diajukan dalam penelitian ini adalah :

H4 : Biaya Operasional terhadap Pendapatan Operasional (BOPO) berpengaruh negatif terhadap Volume Pembiayaan pada Bank Umum Syariah di Indonesia.

e) Pengaruh Financing to Deposit Ratio (FDR) terhadap Volume Pembiayaan.

FDR atau LDR dalam terminologi perbankan konvensional adalah rasio yang menggambarkan sejauh mana simpanan digunakan untuk pemberian pinjaman. Rasio ini juga mengukur tingkat likuiditas, di mana rasio FDR yang tinggi menunjukkan bahwa suatu bank memberikan pinjaman seluruh dananya (loan up) atau relatif tidak likuid (illiquid). Sebaliknya rasio yang rendah menunjukkan bank yang likuid dengan kelebihan kapasitas dana yang siap untuk dipinjamkan. Oleh karena itu, rasio ini juga dapat memberi isyarat apakah suatu pinjaman masih dapat mengalami ekspansi atau sebaliknya harus dibatasi. Berdasarkan penjelasan tersebut, maka dapat disimpulkan bahwa FDR atau LDR berpengaruh terhadap penyaluran pembiayaan. Adapun hipotesis yang diajukan dalam penelitian ini adalah :

H5 : Financing to Deposit Ratio (FDR) berpengaruh positif terhadap Volume Pembiayaan pada Bank Umum Syariah di Indonesia.

Adapun kerangka berfikir dalam penelitian ini dapat dilihat pada gambar berikut: 


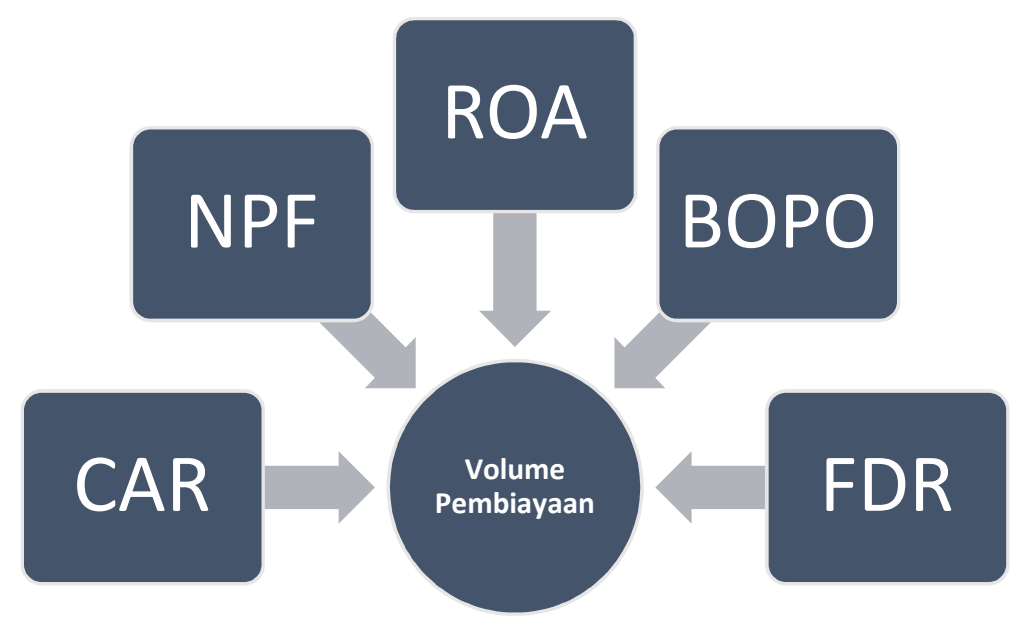

Gambar 1: Model Penelitian

\subsection{Metode Penelitian}

Penelitian ini dilakukan terhadap 13 Bank Umum Syariah yang terdaftar di Otoritas Jasa Keuangan (OJK) dengan data yang tersedia pada tahun 2015-2018. Data tersebut berupa catatan dan perhitungan mengenai Capital Adequacy Ratio (CAR), Non Performing Financing (NPF), Retun on Total Asset (ROA), Rasio Beban Operasional terhadap Pendapatan Operasional (BOPO), Financing to Deposit Ratio (FDR) dan Volume Pembiayaan Bank Umum Syariah yang bersumber dari laporan keuangan bank pada Statistik Perbankan Syariah (SPS) diperoleh langsung dari alamat www.ojk.go.id. Tabel 3 menyajikan daftar Bank Umum Syariah (BUS) yang terdaftar pada database OJK sampai tahun 2018.

Tabel 3: Daftar Bank Umum Syariah di Indonesia Tahun 2018

\begin{tabular}{cl}
\hline No & \multicolumn{1}{c}{ Nama Bank } \\
\hline 1 & PT. Bank Aceh Syariah \\
\hline 2 & PT. Bank Muamalat Indonesia \\
\hline 3 & PT. Bank Victoria Syariah \\
\hline 4 & PT. Bank BRI Syariah \\
\hline 5 & PT. Bank Jabar Banten Syariah \\
\hline 6 & PT. Bank BNI Syariah \\
\hline 7 & PT. Bank Syariah Mandiri \\
\hline 9 & PT. Bank Mega Syariah \\
\hline 10 & PT. Bank Panin Dubai Syariah \\
\hline 11 & PT. BCA Syariah \\
\hline 12 & PT. Maybank Syariah Indonesia \\
\hline 13 & PT. Bank Tabungan Pensiunan Nasional Syariah \\
\hline
\end{tabular}

Sedangkan teknis analisis data dalam penelitian ini menggunakan analisis regresi berganda dengan bantuan software SPSS. 


\section{HASIL DAN PEMBAHASAN}

\subsection{Hasil Analisis Data}

Uji hipotesis digunakan untuk menguji hipotesis penelitian yang telah dirumuskan sebelumnya, yaitu untuk mengetahui pengaruh variabel Capital Adequacy Ratio (CAR), Non Performing Financing (NPF), Return on Asset (ROA), Biaya Operasional terhadap Pendaptan Operasional (BOPO), dan Financing to Deposit Ratio (FDR) terhadap Volume Pembiayaan Bank Umum Syariah.

Sebelum melakukan uji regresi linier berganda, terlebih dahulu dilakukan uji asumsi klasik terhadap seluruh variabel penelitian. Tujuan dilakukannya uji prasyarat asumsi klasik adalah agar model regresi linier memenuhi kondisi BLUE (Best Linier Unblased Estimate) sehingga model regresi valid untuk memprediksi. Hasil pengujian terhadap uji asumsi klasik disajikan di dalam tabel 4, sedangkan hasil pengujian hipotesis penelitian ini disajikan dalam tabel 5 .

Tabel 4: Hasil Uji Asumsi Klasik

\begin{tabular}{|c|c|c|}
\hline Uji Asumsi Klasik & Nilai & Keterangan \\
\hline Uji Normalitas & $\begin{array}{c}\text { Nilai signifikansi (sig) } \\
\text { unstandardized residualnya pada } \\
\text { Kolmogorov-smirnov test } \\
\text { diketahui sebesar } 0,200 .\end{array}$ & $\begin{array}{l}\text { Dapat simpulkan bahwa } \\
\text { residual data menyebar } \\
\text { normal }\end{array}$ \\
\hline Uji Multikolinearitas & $\begin{array}{l}\text { Nilai VIF masing-masing variabel: } \\
\qquad \begin{aligned} \operatorname{VIF}_{x 1}=4,020 \\
\operatorname{VIF}_{x 2}=3,300 \\
\operatorname{VIF}_{x 3}=4,752 \\
\operatorname{VIF}_{x 4}=5,351 \\
\operatorname{VIF}_{x 5}=4,495\end{aligned}\end{array}$ & $\begin{array}{c}\text { cut off } \text { VIF }<10 . \\
\text { Kesimpulan: tidak terjadi } \\
\text { gejala multikoliniaritas antar } \\
\text { variabel bebas dalam model } \\
\text { regresi. }\end{array}$ \\
\hline Uji Autokorelasi & $\begin{array}{c}\text { Hasil uji Durbin-Watson } \\
\text { menunjukkan hasil: } \\
\text { DW }=2,000 \\
\mathrm{dL}=1,2769 \\
\mathrm{dU}=1,7777 \\
4-\mathrm{d} U=2,2223\end{array}$ & $\begin{array}{c}\text { Kriteria: nilai DW berada } \\
\text { diantara nilai dU dan } 4-d U \\
\text { atau du<DW<4-dU. } \\
\text { Kesimpulan: tidak terdapat } \\
\text { gejala autokorelasi positif } \\
\text { maupun negatif pada model } \\
\text { regresi }\end{array}$ \\
\hline Uji Heterokedastisitas & $\begin{array}{l}\text { Hasil: tidak ada pola tertentu yang } \\
\text { dibentuk oleh titik, karena titik } \\
\text { menyebar secara acak di atas dan } \\
\text { di bawah sumbu } 0 \text { pada sumbu Y }\end{array}$ & $\begin{array}{l}\text { Kriteria: tampilan diagram } \\
\text { scatterplot menunjukkan titik- } \\
\text { titik (plot) menyebar secara } \\
\text { acak di atas maupun di bawah } \\
\text { angka nol pada sumbu Y atau } \\
\text { sumbu Regression } \\
\text { Studentized Residual. } \\
\text { Kesimpulan: tidak terjadi } \\
\text { masalah heterokedastisitas. }\end{array}$ \\
\hline
\end{tabular}

Tabel 5: Hasil Uji Hipotesis

\begin{tabular}{|c|c|c|}
\hline Uji Regresi & Nilai & Keterangan \\
\hline Koefisien Regresi & $\begin{array}{c}\text { Nilai Koefisien= } \\
\text { CAR }(X 1)=0,013 \\
\text { NPF }(X 2)=-0,092 \\
\text { ROA }(X 3)=0,111 \\
\text { BOPO }(X 4)=-2,803 \\
\text { FDR }(X 5)=0,342\end{array}$ & $\begin{array}{c}\text { Persamaan Regresi }= \\
\mathrm{Y}=23,478+0,013 \mathrm{X} 1-0,092 \mathrm{X} 2+ \\
0,111 \mathrm{X} 3-2,803 \mathrm{X} 4+0,342 \mathrm{X} 5\end{array}$ \\
\hline Uji t & $\begin{array}{c}\text { Nilai thitung variabel= } \\
\text { CAR }(X 1)=2,207,(0,235)\end{array}$ & Kesimpulan: \\
\hline
\end{tabular}




\begin{tabular}{|c|c|c|}
\hline & $\begin{array}{c}\text { NPF }(X 2)=-2,801,(0,008) \\
\text { ROA }(X 3)=2,327,(0,020) \\
\text { BOPO }(X 4)=-3,934,(0,000) \\
\text { FDR }(X 5)=2,938,(0,354)\end{array}$ & $\begin{array}{l}\text { CAR (X1) tidak berpengaruh } \\
\text { signifikan terhadap volume } \\
\text { pembiayaan bank umum syariah. } \\
\text { NPF (X2) berpengaruh negatif } \\
\text { signifikan terhadap volume } \\
\text { pembiayaan bank umum syariah. } \\
\text { ROA (X3) berpengaruh positif } \\
\text { signifikan terhadap volume } \\
\text { pembiayaan bank umum syariah. } \\
\text { BOPO (X4) berpengaruh negatif } \\
\text { signifikan terhadap volume } \\
\text { pembiayaan bank umum syariah. } \\
\text { FDR (X5) tidak berpengaruh } \\
\text { signifikan terhadap volume } \\
\text { pembiayaan bank umum syariah }\end{array}$ \\
\hline Uji F & $F_{\text {hitung }}=17,034,(0,000)$ & $\begin{array}{c}\text { Kesimpulan: } \\
\text { CAR, NPF, ROA, BOPO dan FDR } \\
\text { secara simultan berpengaruh } \\
\text { signifikan terhadap volume } \\
\text { pembiayaan }\end{array}$ \\
\hline Koefisien Determinasi & Nilai Adjusted $R$ Square $=0,651$ & $\begin{array}{l}\text { 65,1\% variasi perubahan volume } \\
\text { pembiayaan dipengaruhi oleh } \\
\text { variabel CAR, NPF, ROA, BOPO } \\
\text { dan FDR. Sedangkan } 34,9 \% \\
\text { lainnya dipengaruhi oleh variabel } \\
\text { di luar model penelitian }\end{array}$ \\
\hline
\end{tabular}

Sumber: Olah data, 2018

\subsection{Pembahasan}

a) Pengaruh Capital Adequacy Ratio terhadap Volume Pembiayaan Bank Umum Syariah

Hasil pengujian pengaruh CAR terhadap volume pembiayaan menunjukkan nilai

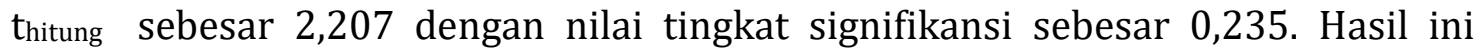
menunjukkan bahwa CAR tidak berpengaruh signifikan terhadap volume pembiayaan. Namun demikian, arah hubungan yang keduanya sesuai dengan hipotesis yang diajukan dalam penelitian ini. Nilai koefisien regresi CAR sebesar 0,013 menunjukkan bahwa pada saat variabel CAR meningkat 1 (satu) satuan maka variabel volume pembiayaan akan naik sebesar 0,013 dengan asumsi variabel lain dianggap tetap. Hasil ini juga mengindikasian bahwa CAR tidak berpengaruh signifikan terhadap volume pembiayaan.

Nilai CAR yang tinggi memungkinkan bahwa bank memiliki modal yang tinggi sehingga bank dapat menyalurkan volume penyaluran kredit yang lebih besar. Selain itu, semakin tinggi CAR maka semakin besar pula sumber finansial yang dapat digunakan untuk keperluan pengembangan usaha dan mengantisipasi potensi kerugian yang diakibatkan oleh penyaluran kredit/atau pembiayaan. Kecukupan modal yang tinggi dan memadai akan meningkatkan volume pembiayaan bank syariah, karena dengan jumlah modal yang besar, bank akan mampu menanggung risiko (Adnan, 2013).

b) Pengaruh Non Performing Financing terhadap Volume Pembiayaan Bank Umum Syariah

Hasil pengujian pengaruh NPF terhadap volume pembiayaan menunjukkan hasil $t_{\text {hitung }}-2,801$ dengan tingkat signifikansi sebesar 0.008 . Nilai koefisien regresi NPF 
sebesar -0,092 yang berarti bahwa pada saat variabel NPF meningkat 1 (satu) satuan maka variabel volume pembiayaan akan turun sebesar -0,092 dengan asumsi variabel lain dianggap tetap. Hal ini menunjukkan bahwa semakin meningkat NPF maka volume pembiayaan semakin menurun. Meningkatnya NPF disebabkan kenaikan pembiayaan yang bermasalah, sehingga perbankan syariah akan lebih berhati-hati dalam menyalurkan pembiayaan untuk meminimalkan timbulnya pembiayaan bermasalah pada tahun berikutnya. Rasio NPF paling menggambarkan tingkat kualitas pembiayaan yang telah disalurkan bank syariah, maka bank wajib menjaga nilai rasio ini agar tetap stabil sesuai dengan peraturan pemerintah di bawah 5\%, jika tingkat NPF tinggi akan mengakibatkan bank mengalami kesulitan dan mempengaruhi tingkat kesehatan bank. Selain itu, meningkatnya NPF akan berpengaruh terhadap modal pembiayaan atau dapat diartikan dana yang tersedia untuk disalurkan kepada masyarakat akan semakin berkurang karena kemampuan bank untuk mengembalikan kembali dana yang disalurkan sangat rendah (Annisa \& Yaya, 2015).

c) Pengaruh Return on Asset terhadap Volume Pembiayaan Bank Umum Syariah

Hasil pengujian pengaruh ROA terhadap volume pembiayaan menunjukkan hasil thitung sebesar 2,327 dengan tingkat signifikansi 0.020. Nilai koefisien regresi ROA sebesar 0,111 menunjukkan bahwa pada saat variabel ROA meningkat 1 (satu) satuan maka variabel volume pembiayaan akan naik sebesar 0,111 dengan asumsi variabel lain dianggap tetap. Hasil penelitian ini sejalan dengan penelitian Heidy Paramitha Devi (2016) yang menunjukkan bahwa Return On Asset (ROA) berpengaruh positif terhadap jumlah penyaluran pembiayaan bank umum syariah di Indonesia. Hal ini menunjukkan bahwa nilai ROA yang tinggi mencerminkan bahwa setiap aset yang dimiliki oleh perusahaan perbankan telah mampu dikelola dengan baik sehingga menghasilkan laba yang nantinya dapat menjadi indikator dalam aktivitas perkreditan perbankan. Semakin tinggi ROA suatu bank maka semakin besar tingkat keuntungan yang dicapai bank tersebut dan semakin baik posisi bank dari segi pengamanan aset terutama aset yang mengandung risiko. Sehingga dapat disimpulkan bahwa pada saat bank akan melakukan penyaluran pembiayaan, bank akan melihat perolehan laba bank ditahun sebelumnya sehingga jika pada tahun lalu laba bank tinggi maka bank dapat menggunakan aset yang dimiliki untuk menghasilkan laba. Perolehan laba tahun lalu yang besar juga akan memotivasi bank meningkatkan keuntungan kembali dengan cara melakukan penyaluran kredit/atau pembiayaan (Retnowati, 2013).

d) Pengaruh Biaya Operasional terhadap Pendapatan Operasional terhadap Volume Pembiayaan Bank Umum Syariah

Hasil pengujian statistik ROA terhadap volume pembiayaan menunjukkan hasil

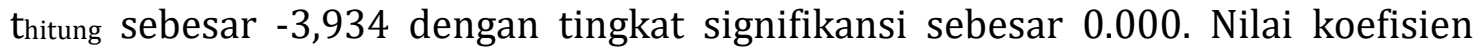
regresi BOPO sebesar -2,803 menunjukkan bahwa pada saat BOPO meningkat 1 (satu) satuan maka variabel volume pembiayaan akan turun sebesar -2,803 dengan asumsi variabel lain dianggap tetap. Penelitian ini sejalan dengan penelitian Masudah yang menunjukkan bahwa BOPO berpengaruh negatif terhadap volumen pembiayaan bank umum syariah. Hal ini disebabkan karena tingkat efisiensi bank dalam menjalankan operasinya berpengaruh terhadap pendapatan yang dihasilkan oleh bank tersebut di mana ketika pendapatan naik mengindikasikan bahwa pembiayaan bermasalah yang dialami oleh bank menurun. Selain itu, apabila 
manajemen bank mampu menekan BOPO berarti efisiensi meningkat dan akan sangat berdampak terhadap kenaikan jumlah pembiayaan yang disalurkan. Hal ini karena dana yang seharusnya digunakan untuk biaya operasional dapat digunakan untuk kegiatan yang lebih menghasilkan laba untuk bank (Desi Ariyani, 2010; Niode \& Chabachib, 2016).

e) Pengaruh Financing to Deposit Ratio terhadap Volume Pembiayaan Bank Umum Syariah

Hasil pengujian pengaruh FDR terhadap volume pembiayaan menunjukkan hasil thitung sebesar 2,938 dengan tingkat signifikansi sebesar 0,354. Nilai koefisien regresi FDR sebesar 0,342 yang berarti bahwa pada saat variabel FDR meningkat 1 (satu) satuan maka variabel volume pembiayaan akan naik sebesar 0,342 dengan asumsi variabel lain dianggap tetap. Hasil penelitian ini mengindikasikan bahwa FDR tidak berpengaruh signifikan terhadap volume pembiayaan bank umum syariah. Namun demikian, arah hubungan FDR dengan volume pembiayaan masih sesuai dengan hipotesis penelitian. Jumlah pembiayaan atas dana masyarat berpengaruh terhadap pembiayaan selanjutnya. Semakin tinggi FDR yang dimiliki oleh bank maka semakin tinggi pula penyaluran kredit bank tersebut. Bank yang memiliki FDR tinggi menunjukkan bahwa bank telah menggunakan dana yang dimiliki untuk aktivitas penyaluran kredit secara tinggi pula. Hal ini disebabkan peningkatan jumlah dana pihak ketiga akan membuat bank bekerja lebih keras lagi untuk menyalurkan dana tersebut supaya tidak terjadi idle fund. Dana yang menganggur akan membuat bank mengeluarkan biaya penyimpanan yang lebih besar yang tidak diimbangi dengan keuntungan yang diterima bank sehingga bank dapat mengalami kerugian.

\section{PENUTUP}

Hasil penelitian ini menunjukkan bahwa secara simultan, CAR, NPF, ROA, BOPO, dan FDR berpengaruh signifikan terhadap besar kecilnya volume pembiayaan yang disalurkan oleh Bank Umum Syariah yang ada di Indonesia. Namun, secara parsial, CAR dan FDR memberikan dampak yang tidak signifikan. Pengawasan ketat dalam penyaluran pembiayaan hendaknya tetap menjadi prioritas dunia perbankan agar tetap dalam kondisi sehat dan mendapatkan kepercayaan dari stakeholdernya.

Terbatasnya variabel yang digunakan dalam penelitian ini merekomendasikan kepada peneliti mendatang untuk mengikutsertakan lebih banyak lagi faktor selain yang ada dalam model penelitian ini seperti rasio leverage, likuiditas, profitabilitas lainnya. Di samping itu juga perlu dipertimbangkan faktor eksternal perusahaan seperti kondisi perekonomian, perubahan nilai tukar, tingkat inflasi, dan juga memperpanjang periode pengamatan.

\section{DAFTAR PUSTAKA}

Adnan, M. akhyar. (2013). Analisis Faktor-Faktor Yang Mempengaruhi Rendahnya Pembiayaan Mudharabah Menurut Perspektif Manajemen Bank Syariah Dengan Pendekatan Kritis. Jurnal Akuntansi \& Investasi. 
Alamsyah, H. (2012). Perkembangan dan Prospek Perbankan Syariah Indonesia : Tantangan Dalam Menyongsong MEA 2015. In Milad ke-8 Ikatan Ahli Ekonomo Islam (IAEI).

Annisa, L. N., \& Yaya, R. (2015). PENGARUH DANA PIHAK KETIGA, TINGKAT BAGI HASIL DAN NON PERFORMING FINANCING TERHADAP VOLUME DAN PORSI PEMBIAYAAN BERBASIS BAGI HASIL PADA PERBANKAN SYARIAH DI INDONESIA. Journal of Islamic Economics and Finance. https://doi.org/10.22373/share.v4i1.754

Arifin Zainul. (2012). Dasar-dasar Manajemen Bank Syariah - Drs. Zainul Arifin,.

Bank Indonesia. (2004). Peraturan Bank Indonesia nomor: 6/10/PBI/2004 tentang sistem penilaian tingkat kesehatan bank umum. Peraturan bank Indonesia. https://doi.org/10.1109/Cvpr.2014.226

Bank Indonesia. (2007). Peraturan Bank Indonesia NO: 9/15/2007. Penerapan Manajemen Risiko Dalam Penggunaan Teknologi Informasi Oleh Bank Umum. https://doi.org/10.1017/CB09781107415324.004

BI. (2013). Surat edaran No. 15/15/DPNP tertanggal 29 April 2013 tentang pelaksanaan good corporate governance bagi bank umum. Bank Indonesia. https://doi.org/http://dx.doi.org/10.1111/j.1728-4465.2011.00288.x

Dendawijaya. (2009). Manajemen Perbankan. Edisi Revisi Sembilan. https://doi.org/2009

Desi Ariyani. (2010). ANALISIS PENGARUH CAR, FDR, BOPO DAN NPF TERHADAP PROFITABILITAS PADA PT BANK MUAMALAT INDONESIA TBK. Al-Iqtishad.

Ibrahim, A., \& Rahmati, A. (2017). Analisis Solutif Penyelesaian Pembiayaan Bermasalah di Bank Syariah : Kajian Pada Produk Murabahah di Bank Muamalat. Jurnal Kajian Ekonomi Dan Bisnis Islam. https://doi.org/10.21043/iqtishadia.v10i1.2319

Ikatan Bankir Indonesia. (2016). Memahami Bisnis Bank. In 5.

Indonesia, R. (2008). Undang-Undang No. 21 Tahun 2008 tentang Perbankan Syariah. Lembaran Negara RI Tahun 2008, No. 94. https://doi.org/10.1029/2004jd004583

Nasih, M., Laila, N., \& Dewikarina. (2013). MANAJEMEN RISIKO PEMBIAYAAN MUDHARABAH PADA PERBANKAN SYARIAH. Media Trend.

Niode, N. N., \& Chabachib. (2016). Pengaruh Car, Pembiayaan, Npf, Dan Bopo Terhadap Roa Bank Umum Syariah Di Indonesia Periode 2010-2015. Diponegoro Journal of Management.

Otoritas Jasa Keuangan. (2017). Statistik Perbankan Indonesia 2017. Statistik Perbankan Indonesia 2017. https://doi.org/VOL: 10 No. 8 JULI 2012

Retnowati, E. (2013). Faktor Yang Mempengaruhi Pembiayaan Murabahah Pada Bank Umum Syariah Di Indonesia. Accounting Analysis Journal. https://doi.org/ISSN 2252-6765 